\title{
高流動コンクリートの流動性に及ぼす粗骨材の影響に関する研究 STUDY ON INFLUENCE OF COARSE AGGREGATE ON FLOWABILITY OF SELF-COMPACTING CONCRETE
}

\author{
宮野和 樹*, 桝 田佳 寛**, 中村成春***, 五 味 信 治**** \\ Kazuki MIYANO, Yoshihiro MASUDA, Shigeharu NAKAMURA \\ and Shinji GOMI
}

\begin{abstract}
The influence of quantity and shape of coarse aggregate and flowability of mortar on flowability of self-compacting concrete is investigated in this study. The coefficient of thickness of mortar layer is introduced based on coefficient of coarse aggregate's shape, quantity of coarse aggregate and solid content in coarse aggregate. The coefficient of coarse aggregate's shape is introduced by projection circumference, projection area, volume and grading of coarse aggregate. The flowability of self-compacting concrete can be estimated by coefficient of thickness of mortar layer and flowability of mortar.
\end{abstract}

Keywords: Self-Compacting Concrete, Shape of Coarse Aggregate, Grading of Coarse Aggregate, Solid Content in Coarse Aggregate, Flowability of Mortar

高流動コンクリート、粗骨材形状、粒度分布、実積率、モルタルの流動性

1. はじめに

高流動コンクリートの流動性に及ぼす調合要因の影響を理論的に 把握する方法として、コンクリートを粗骨材とモルタルまたは骨材 とセメントペーストの二相材料と考え、モルタルやセメントペース

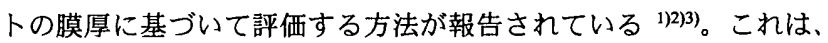
骨材周りの空隙を占めるモルタルやセメントペーストの厚さと流動 性によりコンクリートの流動性を評価するものである。モルタルや セメントペーストの厚さは、骨材量、骨材形状の影響を受けると考 えられる。

一方、一般にコンクリートの流動性に及ぼす粗骨材形状の影響を 評価する場合は、実積率が特性值として用いられることが多いが、 高流動コンクリートの流動性は、実積率のみでは十分に評価できな (4)。湊積率以外に、比表面積なども有用な特性值として考えられ、 それらの特性值を考慮した高流動コンクリートの調合方法を確立す る必要があると考えられる。そこで、粗骨材形状を定量化するため に、粗骨材の表面積または表面積の大小の傾向を表す值を算出する ことにより、膜厚理論に関連づけて、高流動コンクリートの流動性 を評価することができると考えられる。

本研究は、高流動コンクリートの流動性に及ぼす粗骨材量、粗骨 材形状およびモルタルの流動性の影響を実験的に検討したものであ
る。ここで、まず、粗骨材形状と粒度分布を考虑した粗骨材特性值 を提案する。次に、その特性值と実積率および粗骨材絶対容積とを 関連づけ、膜厚理論に基づき実験結果を考察する。さらに、モル夕 ルの流動性を考慮することにより、高流動コンクリートの流動性を 膜厚理論に基づき評価することとした。

\section{2. 粗骨材形状の評価}

\section{1 評価概要}

骨材形状を評価する指標として、骨材体積に対する骨材表面積の 割合が重要である。しかし、骨材表面積を実際に測定することは、 非常に困難である。細骨材の表面積の近似值を求める方法としては、 水透過法により測定する方法 ${ }^{5)}$ ：定水位透水試験により得られた透 水係数と試料の空隙率から算出する方法 ${ }^{67) な と ゙ か ゙ あ る 。 し か し こ れ ~}$ らは粗骨材のように径が大きい骨材の表面積を測定するには適当で はない。粗骨材の表面積の近似值を求める方法としては、粗骨材と 同径の球体の比表面積と粗骨材の表面係数および角張り係数より算 出する方法 ${ }^{8991109}$ 、粗骨材を楕円体で近似し、その直交 3 方向の径を 計測し、それをもとに楕円の面積を求め、その平均の 4 倍を表面積 とする方法 ${ }^{11}$ 、粗骨材の 3 方向の投影面積の平均の 4 倍を表面積と

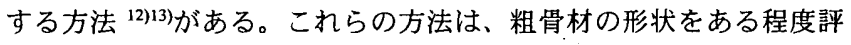

\footnotetext{
* 宇都宮大学大学院工学研究科 大学院生. 修士(工学)

** 宇都宮大学工学部建设学科 教授・工博

*** 宇都宮大学工学部建設学科 助教授・工博

****クんかい日産建設侏技術研究所 所長

Graduate Student, Graduate School of Engineering; Utsunomiya Univ., M. Eng. Prof., Dept. of Architecture and Civil Engineering, Faculty of Engineering, Utsunomiya Univ., Dr. Eng.

Assoc. Prof., Dept. of Architecture and Civil Engineering, Faculty of Engineering, Utsunomiya Univ., Dr. Eng.

General Manager, Research and Development Institute, Nissan Rinkai Construction
} 
価していると考えられるが、粗骨材のふくらみ具合や表面の凹凹は 十分に反映できていないと考えられる。ここで、ふくらみ具合とは、 図ー1に示すように、3 方向の径は各々同じであるが、形状が異な るという意味である。これらの形状の粗骨材では、それぞれコンク リートの流動性に及ぼす影響が異なると考えられるが、これらを楕 円体で仮定するとすべてを同じ形状として捉えることになる。また、 表面の凹凹とは、概念図で示すと、図ー 2 に示すような違いのこと である。図ー 2 において、面積および周長は、凹凸なしの值を 1.00 とした場合の比を凹凸ありに示した。これらの形状の粗骨材につい ても、それぞれコンクリートの流動性に及ぼす影響が異なると考え られるが、投影面積で仮定すると同じ形状として捉えることになる。 そこで、本研究では、粗骨材の体積に対する表面積の代わりに、粗 骨材の投影面積に対する投影周長を求め、粗骨材の投影単位面積あ たりの周長を算出した。この粗骨材の単位面積あたりの周長は、粗 骨材体積に対する粗骨材表面積の大小の傾向を表していると考えら れる。粗骨材の体積の影響をなくすため、単位体積あたりの単位面 積周長を求め、さらに、単位体積あたりの粗骨材の各ふるいの残留 体積を用い、粒度分布を考虑した值を求めた。この值を粗骨材形状 係数とし、粗骨材体積に対する表面積の傾向を表す特性值と考えた。

\section{2 . 2 使用材料}

使用した粗骨材の種類および特性を表ー 1 に、粗骨材の粒度分布 を表一 2 に示す。粗骨材は、硬質砂岩砕石、石灰岩砕石、川砂利の 3 種類とし、実積率がそれぞれ 59.9\%、61.0\%、65.3\%と異なる。ま た、粒度分布は 3 種類ともほぼ同程度の值となった。

\section{3 測定方法}

各粗骨材を、5〜 10mm（以下 1005 とする)、10〜 $15 \mathrm{~mm}$ (以下 1510 とする)、15 20mm（以下 2015 とする)、20～25mm（以下 2520 と する）の粒度範囲にふるいを用いて分級し、粒度範囲 $1005 、 1510$ では 30 個を、粒度範囲 2015 では 10 個を、粒度範囲 2520 では 5 個 を四分法により無作為抽出して測定試料とした。粒度範囲 2015 、 2520 は、粒度分布において占める割合が小さく影響が少ないため、 測定試料数を少なくした。

各粗骨材において図ー 3 に示すように、粗骨材の最長径を基準と し、直交 3 方向の画像 I、II、III をデジタルカメラにより撮影した。 一つの粗骨材について、より多くの方向からの粗骨材画像を用いる ことが望ましいが、計測上の利便性の観点から、直交 3 方向であれ ば、粗骨材全体の形状を評価することができると考えられるため、 直交 3 方向を用いた。次に、パソコン内に画像を読み込み、その画 像をトレースした。また、粗骨材個々について絶乾質量を測定し、 絶乾密度により体積を算出した。

\section{4 評価方法}

各粗骨材の投影周長、投影面積、体積を用いて、粗骨材種類の違 いによる形状の差異と粗骨材の粒度分布を考慮した粗骨材形状係数 を以下のように算出した。

まず、粒度範囲 $i$ の $j$ 個目の粗骨材単体の単位面積あたりの周長 $L_{i j}$ は次式で算出した。

$$
L_{i j}=\frac{\frac{L_{i j 1}}{S_{i j 1}}+\frac{L_{i j \mathrm{II}}}{S_{i j \mathrm{II}}}+\frac{L_{i j \mathrm{mI}}}{S_{i j \mathrm{MI}}}}{3}
$$
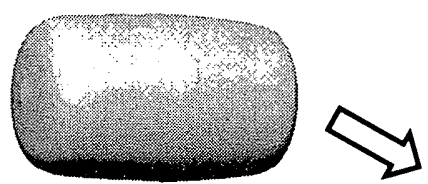

体積に対する 表面積の割合 は各々異なる。
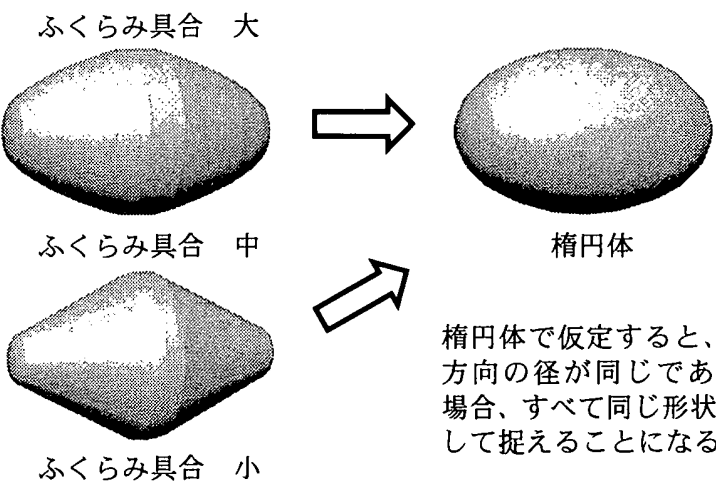

楕円体

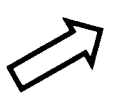

楕円体で仮定すると、3 方向の径が同じである 場合、すべて同じ形状と して捉えることになる。

\section{図ー1 ふくらみ具合の概念}
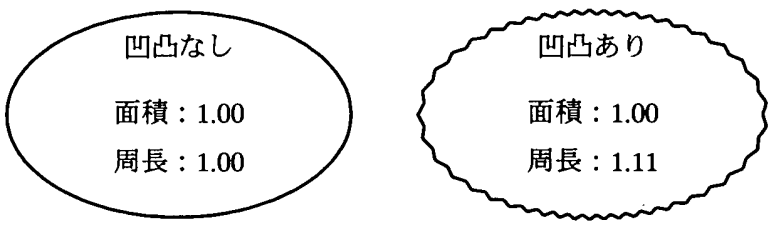

図ー2 表面の凹凸の概念

\begin{tabular}{c|c}
\multicolumn{2}{|c}{ 表 -1 粗骨材の種類および特性 } \\
\hline 種類 & 特性 \\
\hline 硬質砂岩砕石 & $\begin{array}{c}\text { 表乾密度 } 2.66 \mathrm{~g} / \mathrm{cm}^{3} \text { 、絶乾密度 } 2.64 \mathrm{~g} / \mathrm{cm}^{3} \\
\text { 吸水率 } 0.82 \% \text { 、奉積率 } 59.9 \%\end{array}$ \\
\hline 石灭岩砕石 & $\begin{array}{c}\text { 表乾密度 } 2.71 \mathrm{~g} / \mathrm{cm}^{3} \text { 、絶乾密度 } 2.70 \mathrm{~g} / \mathrm{cm}^{3} \\
\text { 吸水率 } 0.28 \% \text { 、奏積率 } 61.0 \%\end{array}$ \\
\hline 川砂利 & $\begin{array}{c}\text { 表乾密度 } 2.60 \mathrm{~g} / \mathrm{cm}^{3} \text { 、絶乾密度 } 2.56 \mathrm{~g} / \mathrm{cm}^{3} \\
\text { 吸水率 } 1.49 \% \text { 、㬰積率 } 65.3 \%\end{array}$ \\
\hline
\end{tabular}

表-2 粗骨材の粒度分布

\begin{tabular}{c|c|c|c|c|c|c}
\hline \multirow{2}{*}{ 種類 } & \multirow{2}{*}{ 粗粒率 } & \multicolumn{5}{|c}{ ふるいの通過質量百分率(\%) } \\
\cline { 3 - 7 } & & $25 \mathrm{~mm}$ & $20 \mathrm{~mm}$ & $15 \mathrm{~mm}$ & $10 \mathrm{~mm}$ & $5 \mathrm{~mm}$ \\
\hline 硬質砂岩砕石 & 6.67 & 100 & 96 & 81 & 37 & 0 \\
\hline 石灰岩砕石 & 6.67 & 100 & 95 & 81 & 37 & 0 \\
\hline 川砂利 & 6.66 & 100 & 95 & 82 & 39 & 0 \\
\hline
\end{tabular}

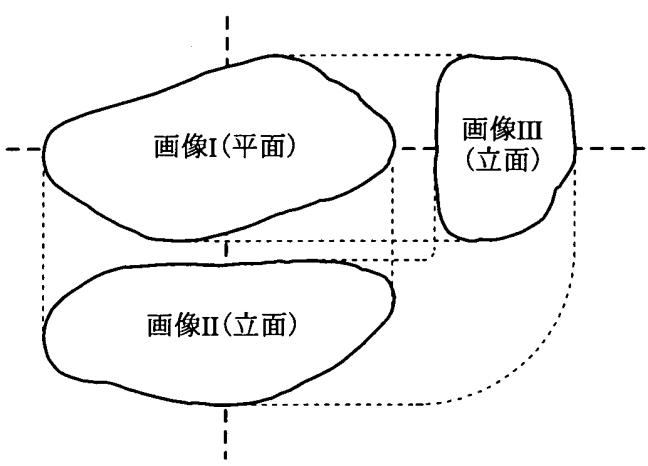

図-3 粗骨材の撮影方向 
ここに、 $L_{i j \mathrm{I}} 、 L_{i j \mathrm{IL}} 、 L_{i j \mathrm{III}}$ : 粒度範囲 $i$ の $j$ 個目の粗骨材画像 I、II、III の投影周長 $(\mathrm{cm}) 、 S_{i j \mathrm{I}} 、 S_{i j \mathrm{II}} S_{i j \mathrm{III}}$ : 粒度範囲 $i$ の $j$ 個目の粗骨材画像 I、 II、III の投影面積 $\left(\mathrm{cm}^{2}\right)$

次に、粒度範囲 $i$ の粗骨材 $1 \mathrm{~cm}^{3}$ あたりの単位面積周長 $L_{i}$ を次式で 算出した。

$$
L_{i}=\frac{\sum_{j=1}^{N} \frac{L_{i j}}{V_{i j}}}{N}
$$

ここに、 $V_{i j}$ : 粒度範囲 $i$ の $j$ 個目の粗骨材体積 $\left(\mathrm{cm}^{3}\right) 、 N$ : 各粒度範囲 の粗骨材の個数(個)

最終的に、粗骨材種類ごとに形状の差異と粒度分布を考虑した粗 骨材形状係数 $L$ を次式で算出した。

$$
L=\sum L_{i} V_{i}
$$

ここに、 $V_{i}$ : 全粗骨材が $1 \mathrm{~cm}^{3}$ である場合の粒度範囲 $i$ の粗骨材体積 $\left(\mathrm{cm}^{3}\right)$

\section{5 計算結果および考察}

粗骨材種類ごとの $L_{i}$ および $L$ の計算結果を表 -3 に示す。 $L_{i}$ は、 粒度範囲 2520、2015 では、粗骨材種類による相違はみられないが、 粒度範囲 1510、1005 では、硬質砂岩砕石が他の 2 種類より大きく、 石灰岩砕石および川砂利は同程度の值となった。Lは、粒度範囲 1510 、 1005 の $L_{i}$ と同様に、硬質砂岩砕石が他の 2 種類より大きく、石灰岩 砕石および川砂利は同程度の值となった。これは、粗骨材 $1 \mathrm{~cm}^{3}$ あた りの各粒度笧囲における粗骨材の体積が粒度範囲 1510.1005 におい て大きいために粒度範囲 1510、1005の $L_{i}$ と同様の傾向になったと 考えられる。最終的に求められた $L$ は粗骨材のふくらみ具合および 表面の凹凹を考慮することができたと考えられる。

\section{3.コンクリート試験における粗骨材形状の影響評価 \\ 3. 1 要因と水準および使用材料}

粗骨材種類は、表一 1 と同様で、硬質砂岩砕石、石灰岩砕石、川 砂利の 3 種類とした。対象とした高流動コンクリートは、普通ポル トランドセメントと高炬スラグ微粉末を質量比で 1:1 に混合したも のを結合材とした。水結合材比は 45\%、細骨材とモルタルの体積比 （以下 $\mathrm{s} / \mathrm{m}$ とする）は $55 \%$ 、高性能 $\mathrm{AE}$ 減水剤の添加率は結合材の 質量に対して $1.05 \%$ 、分離低減剤の添加率は水の質量に対して $0.08 \%$ とし、すべてにおいて一定とした。目標空気量は $2.0 \pm 1.0 \%$ とし、 測定結果は、いずれも目標空気量の範囲内であった。実験の要因と 水準を表一 4 に、粗骨材以外の使用材料を表一 5 に示す。

\section{2 試験項目および試験方法}

高流動コンクリートの試験項目として、スランプフロー試験、 $50 \mathrm{~cm}$ フロー到達時間および空気量を測定した。スランプフロー試験 は、JIS A 1150 に準じて行い、試料の詰め方は、 3 層に分けて詰め、 各層の突き回数を 5 回として行った。空気量試験もスランプフロー 試験と同様に、3 層に分けて詰め、各層の突き回数を 5 回として行 った。
表一 $3 \quad L_{i}$ および $L$ の計算結果

\begin{tabular}{c|c|c|c|c||c}
\hline \multirow{2}{*}{ 粗骨材種類 } & \multicolumn{4}{|c||}{ 粒度範囲 $i \sigma L_{i}$} & \multirow{2}{*}{$L$} \\
\cline { 2 - 6 } & 2520 & 2015 & 1510 & 1005 & \\
\hline 硬質砂岩砕石 & 0.38 & 0.55 & 1.71 & 21.26 & 8.73 \\
\hline 石灰岩砕石 & 0.33 & 0.60 & 1.46 & 17.64 & 7.34 \\
\hline 川砂利 & 0.25 & 0.41 & 1.36 & 16.68 & 7.20 \\
\hline
\end{tabular}

表 -4 要因と水準

\begin{tabular}{c|c}
\hline 要因 & 水準 \\
\hline & 硬質砂岩砕石 $(59.9 \%)$ \\
石灰岩砕石 $(61.0 \%)$ \\
川砂利 $(65.3 \%)$
\end{tabular}

\begin{tabular}{|c|c|c|}
\hline 材料 & 種類 & 特性・主成分 \\
\hline \multirow{2}{*}{ 結合材 } & $\begin{array}{c}\text { 普通ポルト } \\
\text { ランドセメント }\end{array}$ & $\begin{array}{c}\text { 密度 } 3.16 \mathrm{~g} / \mathrm{cm}^{3} \\
\text { 比表面積 } 3290 \mathrm{~cm}^{2} / \mathrm{g}\end{array}$ \\
\hline & $\begin{array}{c}\text { 高炬スラグ } \\
\text { 微粉末 }\end{array}$ & $\begin{array}{c}\text { 密度 } 2.90 \mathrm{~g} / \mathrm{cm}^{3} \\
\text { 比表面樻 } 4900 \mathrm{~cm}^{2} / \mathrm{g} \\
\end{array}$ \\
\hline 細骨材 & 大井川水系陸砂 & $\begin{array}{c}\text { 密度 } 2.59 \mathrm{~g} / \mathrm{cm}^{3} \\
\text { 吸水率 } 2.01 \% \text { 、粗粒率 } 2.56\end{array}$ \\
\hline \multirow{2}{*}{ 混和剂 } & 高性能AE減水剂 & ポリカルボン酸系 \\
\hline & 分離低減剤 & セルロースエーテル系 \\
\hline
\end{tabular}

表 -5 使用材料
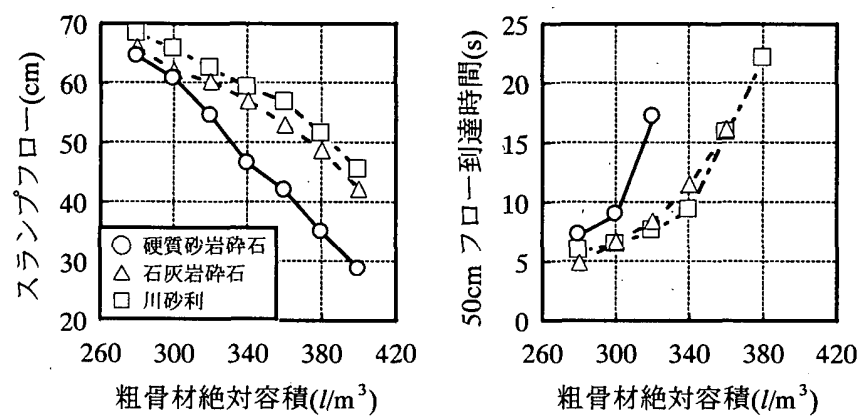

図-4 試験結果

コンクリートの練混ぜは、温度 $20 \pm 1^{\circ} \mathrm{C}$ の室内で、容量 $50 l$ のパ ン型強制練りミキサを用いて、1 回の練混ぜ量を $40 l$ で行った。練 混ぜ手順は、結合材、細骨材、分離低減剤をミキサに投入後、15 秒 間空練りした後、水、高性能 $\mathrm{AE}$ 減水剂を投入し、30 秒間練混ぜた。 かき落としをし、さらに 60 秒間練混ぜた後、粗骨材を投入し 90 秒 間練混ぜた。300 秒静置した後排出し、直ちに試験を行った。

\section{3 . 3 実験結果}

試験結果を図ー 4 に示す。粗骨材絶対容積が大きくなるとスラン プフローは小さくなり、 $50 \mathrm{~cm}$ フロー到達時間は大きくなな。粗骨材 種類ごとに比較すると、スランプフローにおいて、石灰岩砕石と川 砂利は同程度の值および傾向を示している。しかし、硬質砂岩砕石 は他の 2 種類より小さくなり、粗骨材絶対容積が $320 \mathrm{l} / \mathrm{m}^{3}$ 以上にな ると减少度合いが他の 2 種類より大きくなる。 $50 \mathrm{~cm}$ フロー到達時間 においては、石灰岩砕石と川砂利は同程度の值および傾向を示して おり、硬質砂岩砕石は他の 2 種類より值が大きくなる。困より硬質 砂岩砕石が他の 2 種類より流動性が劣り、石灰岩砕石と川砂利は同 
程度の流動性であることがわかる。この傾向は、使用した粗骨材の 粒度分布および粗粒率は同程度の值であるため、粒度分布および粗 粒率の影響を受けたとは考えられない。また、実積率は、硬質砂岩 砕石 $59.9 \%$ 、石井岩砕石 $61.0 \%$ 、川砂利 $65.3 \%$ 、硬質砂岩砕石と石 灰岩砕石の值が近く、実積率のみの影響を受けたとも考えられない。 これらのことから、高流動コンクリートの流動性には、粗骨材の形 状も大きく影響を及ぼていると考えられる。

\section{4 モルタル膜厚係数における評価}

高流動コンクリートの流動性に及ぼす粗骨材形状の影響を評価す るためには、粗骨材の実積率と粗骨材のふくらみ具合および表面の 凹凸を同時に考慮する必要があると考えられる。これらを同時に考 慮するため、粗骨材形状係数 $L$ は粗骨材の比表面積の傾向を表して いると考え、瞙厚理論を用いて考察することとした。膜厚の概念を 図ー 5 に示す。まず、モルタルの総体積から粗骨材の最密充填状態 時の空隙体積を引いたものを余剩モルタル体積とした。コンクリー 卜 $1 \mathrm{~cm}^{3}$ について、余剩モルタルの体積 $V_{S M}$ を次式で算出した。

$$
V_{S M}=\left(1-V_{g}\right)-\frac{V_{g}(100-G)}{G}
$$

ここに、 $V_{g}$ : コンクリート $1 \mathrm{~cm}^{3}$ 中の粗骨材体積 $\left(\mathrm{cm}^{3}\right) 、 G:$ 粗骨材の 実積率 $(\%)$

モルタル膜は、粗骨材の大きさにかかわらず一定の厚さになると 考え、モルタル膜厚係数 $d_{M}$ を次式で定義した。なお、モルタル膜厚 倸数 $d_{M}$ の次元は長さ $(\mathrm{cm})$ となる。

$$
d_{M}=\frac{V_{S M}}{V_{g} \times L}
$$

計算した各調合のモルタル膜厚係数 $d_{M}$ を表 -6 に示す。

モルタル膜厚係数 $d_{M}$ と各試験値の関係を図一 6 に示す。 $d_{M}$ が大 きくなると、スランプフローは大きくなり、 $50 \mathrm{~cm}$ フロー到達時間は 小さくなる。図よりいずれも一本の曲線で示すことができると考え られるため、スランプフローは対数関数で近似し、 $50 \mathrm{~cm}$ フロー到達 時間は指数関数で近似した。図より、モルタル瞙厚係数 $d_{M}$ を用いる ことによって粗骨材種類にかかわらず高流動コンクリートのスラン プフロー、 $50 \mathrm{~cm}$ フロー到達時間を推定できると考えられる。

また、これまでに提案されている、粗骨材を楕円体で近似し表面 積を算出する方法 ${ }^{11)}$ や粗骨材の投影面積より表面積を算出する方法 12)133により求めた表面積から計算したモルタル膜厚と各試験值の関 倸をそれぞれ図ー7、8に示す。なお、それぞれの方法で表面積を 算出する際に用いた粗骨材は粗骨材形状係数 $L$ を算出するときに用 いた粗骨材と同じものを用いた。図ー6、7、8を比較すると、図 一 6 が最も良く評価できており、これより、粗骨材形状を粗骨材形 状係数 $L$ で評価し、モルタル膜厚倸数 $d_{M}$ を用いる方法が有効である ことがわかる。

\section{4. コンクリート試験におけるモルタル流動性の影響評価}

\section{1 実験概要}

高流動コンクリートの流動性に及ぼすモルタルの流動性の影響を

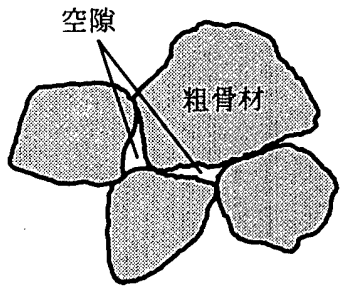

粗骨材の最密充填状態

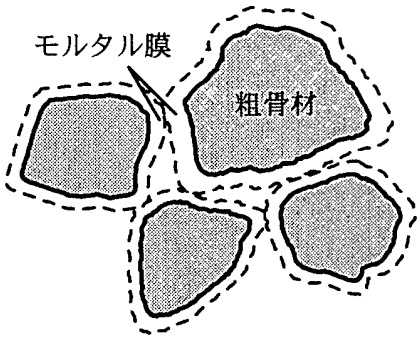

実際のゴンクリートの状態
図 -5 膜厚の概念

\begin{tabular}{|c|c|c|c|}
\hline \multirow{2}{*}{$\begin{array}{c}\text { 粗骨材 } \\
\text { 絶対容積 } \\
\left(l / \mathrm{m}^{3}\right) \\
\end{array}$} & \multicolumn{3}{|c|}{ 粗骨材種類 } \\
\hline & 硬質砂岩砕石 & 石灰岩砕石 & 川砂利 \\
\hline 280 & 0.218 & 0.263 & 0.283 \\
\hline 300 & 0.191 & 0.231 & 0.250 \\
\hline 320 & 0.167 & 0.202 & 0.221 \\
\hline 340 & 0.146 & 0.177 & 0.196 \\
\hline 360 & 0.127 & 0.155 & 0.173 \\
\hline 380 & 0.110 & 0.135 & 0.153 \\
\hline 400 & 0.095 & 0.117 & 0.135 \\
\hline
\end{tabular}

表 -6 各調合のモルタル膜厚係数 $d_{M}$
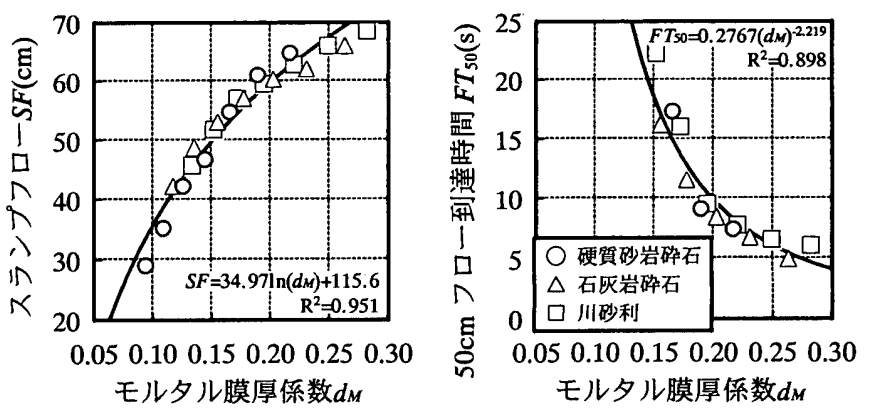

図-6 モルタル膜厚係数 $d_{M}$ と各試験值の関係
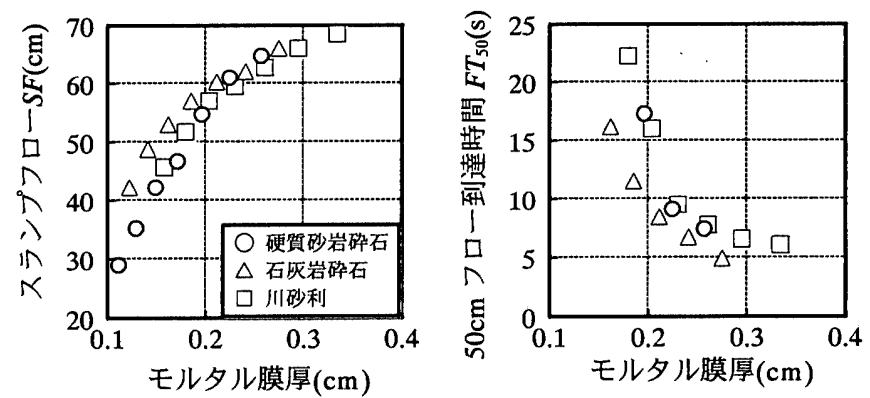

図-7 モルタル膜厚と各試験值の関係

（粗骨材を楕円体と仮定し、表面積を算出）
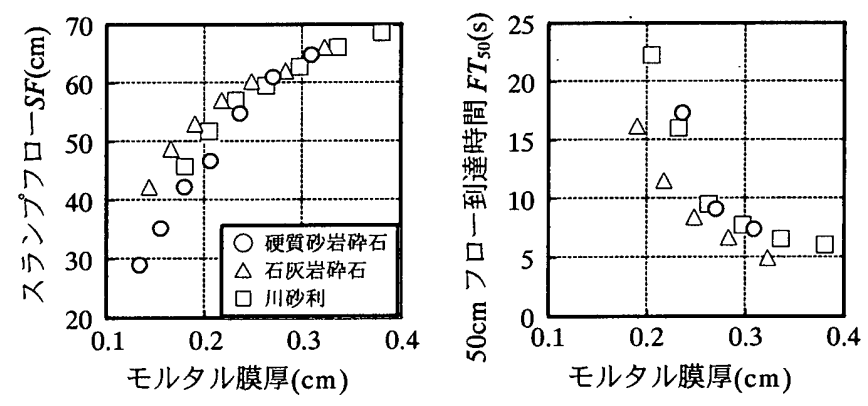

図-8 モルタル膜厚と各試験値の関係 （粗骨材の投影面積より表面積を算出） 
検討するために、3.とは調合の異なるコンクリートについて検討し た。モルタルは、コンクリートの調合から粗骨材を除いた調合のモ ルタル（以下モルタルとする）の流動性を用いて評価した。要因と 水準を表一 7 に、使用材料を表一 8 に示す。対象とした高流動コン クリートは、3.のコンクリートと同様に、普通ポルトランドセメン トと高炬スラグ微粉末を質量比で 1:1 に混合したものを結合材とし、 水結合材比は $45 \%$ 一定とした。高性能 $\mathrm{AE}$ 減水郕の添加率は結合材 の質量に対して、s/m49\%では $1.10 \% 、 \mathrm{~s} / \mathrm{m} 52 \%$ では $1.45 \% 、 \mathrm{~s} / \mathrm{m} 55 \%$ では $1.80 \%$ とした。分離低減剤の添加率は、水の質量に対して、

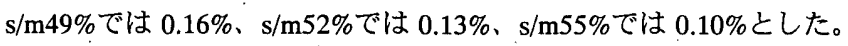
粗骨材は、硬質砂岩砕石のみとした。

試験項目として、コンクリートでは、スランプフロー、 $50 \mathrm{~cm}$ フロ 一到達時間を、モルタルでは、フローおよび $\mathrm{J} 14$ 漏斗流下時間を測 定した。モルタルフ、ロー試験は、JIS R 5201 のフローコーンを用い、 落下回数を 0 回として行った。

コンクリートの練混ぜは、3.と同様に行った。モルタルの練混ぜ は、温度、ミキサ、練混ぜ量は、コンクリートと同様とした。練混 ぜ手順は、結合材、細骨材、分離低減郕をミキサに投入後、15 秒間 空練りした後、水、高性能 $\mathrm{AE}$ 減水剤を投入し、30 秒間練混ぜた。 かき落としをし、さらに 60 秒間練混ぜた。 300 秒静置した後排出し、 直ちにモルタル試験を行った。

\section{2 実験結果および考察}

コンクリート試験結果を図ー 9 に示す。スランプフロー、 $50 \mathrm{~cm}$ フ ロー到達時間ともに 3 .の試験結果と同様の傾向となる。図一 4 と比 較すると、スランプフローは、やや大きく、 $50 \mathrm{~cm}$ フロー到達時間は やや小さくなる。

モルタル試験結果を図ー 10 に示す。モルタルの流動性を比較す るため $3 . の$ 材料および調合で行った試験結果も同時に示す。モル夕 ルフローは、スランプフローの傾向と同様に 3 .で示した值よりやや 大きくなる。 $\mathrm{J} 14$ 漏斗流下時間も、 $50 \mathrm{~cm}$ フロー到達時間の傾向と同 様に 3. .值よりやや小さくなる。コンクリートの傾向とモルタルの 傾向が同様であることより、モルタルの流動性がコンクリートの流 動性に大きく影響を及ぼしていることがわかる。

ここで、モルタルの流動性を考慮するため、モルタル瞙厚係数 $d_{M}$ を用いて評価することとした。4.の実験で用いた材料および調合よ りモルタル膜厚係数 $d_{M}$ を 3 .と同様に算出した。モルタル膜厚係数 $d_{M}$ と各試験值の関係を図 -11 に示す。 $\mathrm{s} / \mathrm{m} 49 、 52 、 55 \%$ ずれも、 スランプフローでは 3. の結果より大きく、 $50 \mathrm{~cm}$ フロー到達時間で は3.の結果より小さくなる。これは、モルタル膜厚係数 $d_{M}$ のみで は、粗骨材形状の影響しか捉えることができないためである。そこ で、モルタルの流動性を考虑するために、相対フロー $F_{R}$ : 相対時間 $T_{R}$ を用いる7こととした。相対フロー $F_{R}$ ，相対時間 $T_{R}$ は、次式で定 義した。

$$
\begin{gathered}
F_{R}=\frac{S F}{F_{m}} \\
T_{R}=\frac{F T_{50}}{T_{J 14}}
\end{gathered}
$$

ここに、 $S F$ : スランプフロー $(\mathrm{cm}) 、 F_{m}:$ モルタルフロー $(\mathrm{cm}) 、 F T_{50}$ : $50 \mathrm{~cm}$ フロー到達時間(s)、 $T_{J 14}: \mathrm{J} 14$ 漏斗流下時間(s)
表 -7 要因と水準

\begin{tabular}{c|c}
\hline 要因 & 水準 \\
\hline 細骨材モルタル比 $(\%)$ & $49 、 52 、 55$ \\
\hline 粗骨材絶対容積 $\left(l / \mathrm{m}^{3}\right)$ & $240 、 270 、 300 、 330 、 360$ \\
\hline $\begin{array}{c}\text { 高性能AE減水剤の添加率 }(\mathrm{B} \times \%) \\
{[\text { 細骨材モルタル比 }(\%)]}\end{array}$ & $1.10[49] 、 1.45[52] 、 1.80[55]$ \\
\hline $\begin{array}{c}\text { 分離低減剤の添加率(W×\%) } \\
{[\text { 細骨材モルタル比 }(\%)]}\end{array}$ & $0.16[49] 、 0.13[52] 、 0.10[55]$ \\
\hline
\end{tabular}

\begin{tabular}{|c|c|c|}
\hline 材料 & 種類 & 特性・主成分 \\
\hline \multirow{2}{*}{ 結合材 } & $\begin{array}{l}\text { 普通ポルト } \\
\text { ランドセメント }\end{array}$ & $\begin{array}{c}\text { 密度 } 3.16 \mathrm{~g} / \mathrm{cm}^{3} \\
\text { 比表面積 } 3320 \mathrm{~cm}^{2} / \mathrm{g}\end{array}$ \\
\hline & $\begin{array}{c}\text { 高炬スラグ } \\
\text { 微粉末 } \\
\end{array}$ & $\begin{array}{l}\text { 密度 } 2.89 \mathrm{~g} / \mathrm{cm}^{3} \\
\text { 比表面積 } 4320 \mathrm{~cm}^{2} / \mathrm{g}\end{array}$ \\
\hline 細骨材 & 大井川水系陸砂 & $\begin{array}{c}\text { 密度 } 2.60 \mathrm{~g} / \mathrm{cm}^{3} \\
\text { 吸水率 } 2.12 \% \text { 、粗粒率 } 2.74\end{array}$ \\
\hline 粗骨材 & 硬質砂岩砕石 & $\begin{array}{c}\text { 表乾密度 } 2.65 \mathrm{~g} / \mathrm{cm}^{3} \\
\text { 吸水率 } 0.67 \% \text { 、実積率 } 60.1 \% \text {. }\end{array}$ \\
\hline \multirow{2}{*}{ 混和凧 } & 高性能AE減水剈 & ポリカルボン酸系 \\
\hline & 分離低减剤 & セルロースエーテル系 \\
\hline
\end{tabular}

表一 8 使用材料
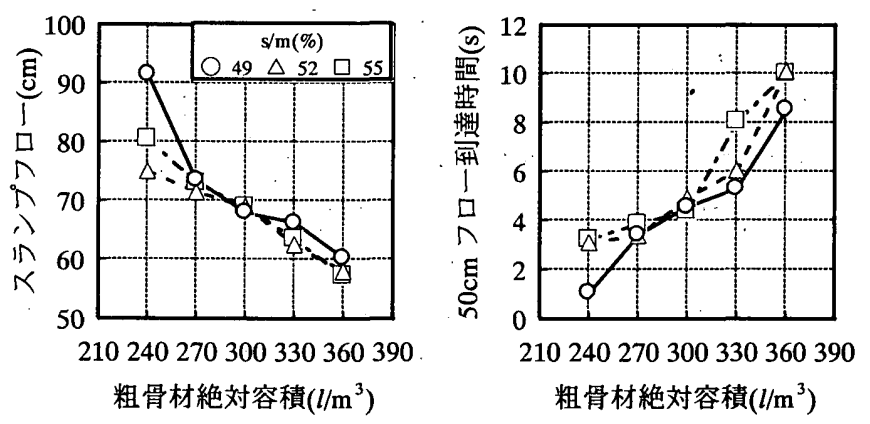

図－9 コンクリート試験結果

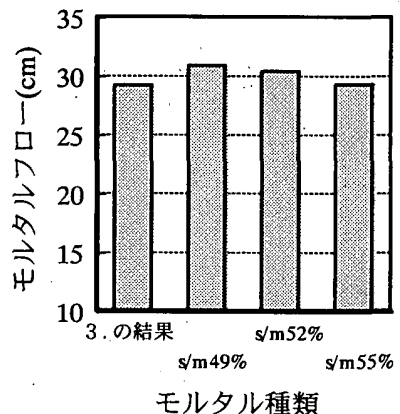

図 -10

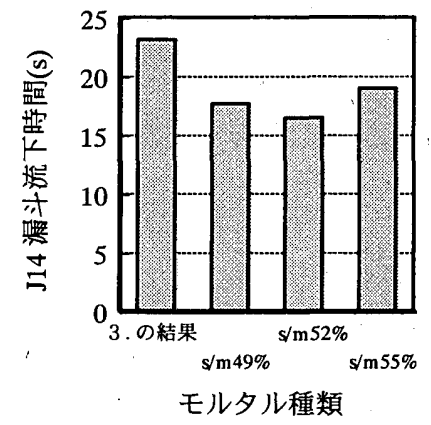

モルタル試験結果
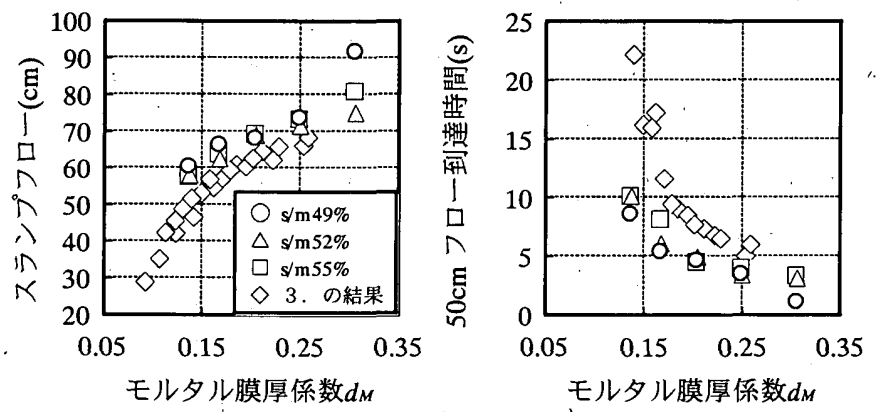

図-11 モルタル膜厚係数 $d_{M}$ と各試験值の関係 
モルタル膜厚係数 $d_{M}$ と相対フロー $F_{R}$ 、相対時間 $T_{R}$ の関保を図一 12 に示す。それぞれ、対数関数、指数関数で近似すると一本の曲 線で示せ、概ね良く評価できている。

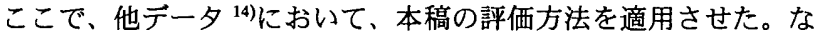
お、粗骨材は硬質砂岩砕石を用いていたため、2、で算出した硬質砂 岩砕石の $L_{i}$ を用い、粗骨材形状倸数 $L$ を算出した。他データと本研 究データの評価結果の比較を図ー 13 に示す。比較のため、図ー 1 2 における近似曲線も同時に示した。モルタル膜厚係数 $d_{M}$ が小さい 場合、多少バラツキがみられるものの、概ね良く評価できている。

これより、モルタル膜厚係数 $d_{M}$ 之相対フロー $F_{R}$ および相対時間 $T_{R}$ を用いることによって、粗骨材形状、モルタルの流動性の違いに かかわらず高流動コンクリートのスランプフロー、 $50 \mathrm{~cm}$ フロー到達 時間を推定できると考えられる。

\section{5. まとめ}

高流動コンクリートの流動性に及ぼす粗骨材量、粗骨材形状およ びモルタルの流動性の影響を実験的に検討した結果、以下のことが 明らかとなった。

(1)粗骨材の投影周長、投影面積、体積および粒度分布を考慮した粗 骨材形状係数 $L$ を用いることによって、粗骨材形状を定量化する ことができた。

(2)粗骨材形状係数 $L$ と粗骨材実積率より算出されたモルタル膜厚係 数 $d_{M}$ を用いることによって、粗骨材種類にかかわらず高流動コン クリートのスランプフロー、 $50 \mathrm{~cm}$ フロー到達時間を推定できた。

(3)モルタル膜厚係数 $d_{M}$ と相対フロー $F_{R}$ および相対時間 $T_{R}$ の関係は、 定式化することができる。すなわち、粗骨材量、粗骨材形状およ びモルタルの流動性より高流動コンクリートのスランプフロー、 $50 \mathrm{~cm}$ フロー到達時間を推定できることが示された。

\section{謝辞}

本研究の害験を進めるにあたり、りんかい日産建設(株) 岡本將昭 氏、当時宇都宮大学卒論生 小川原一太君、香川清児君にご協力いた だきました。ここに記して謝意を表します。

\section{参考文献}

1) 呉相均、野口貫文、友沢史紀 : 余剩ペースト膜厚を用いた高流動コンク リートのレオロジー定数の予測、材料、Vol.48、No.10、pp.1193-1198、1999.10 2) 緑川猛彦、G.I.Pelova、J.C.Walraven : 粒度分布の異なる細骨材を用いた高 流動モルタルへの水膜モデルの適用、コンクリート工学年次論文集、 Vol.23、No.2、pp.943-948、2001

3) 日本コンクリートエ学協会 : フレッシュコンクリートのカ学モデル研究 小委員会報告書、1996.4

4) 高山俊一、江頭智嘉、巽勇二 : 種類が異なる骨材の混合と高流動コンク リートの流動性、コンクリート工学年次論文集、Vol.24、No.1、pp.891-896、 2002

5) 近田孝夫、前田悦孝、松下博通 : 余䣋ペースト膜厚理論における骨材の 形状評価とモルタルの流動性に関する研究、コンクリート工学年次論文報 告集、Vol.18、No.1、pp.441-446、1996
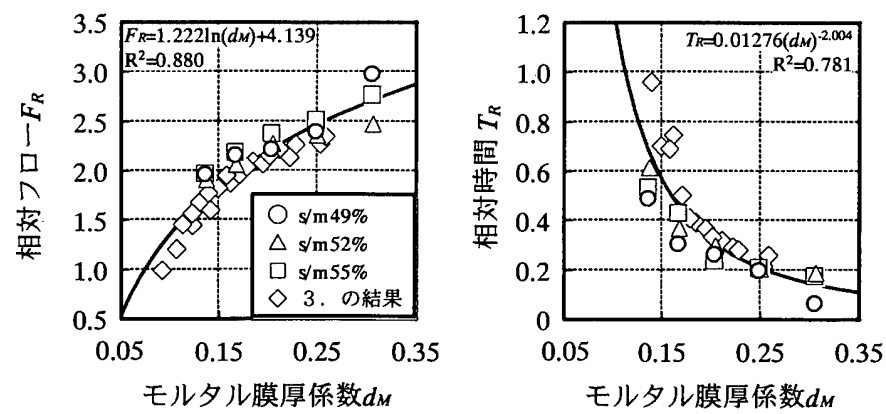

図-12 モルタル膜厚係数 $d_{M}$ と

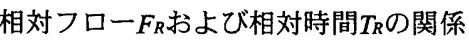
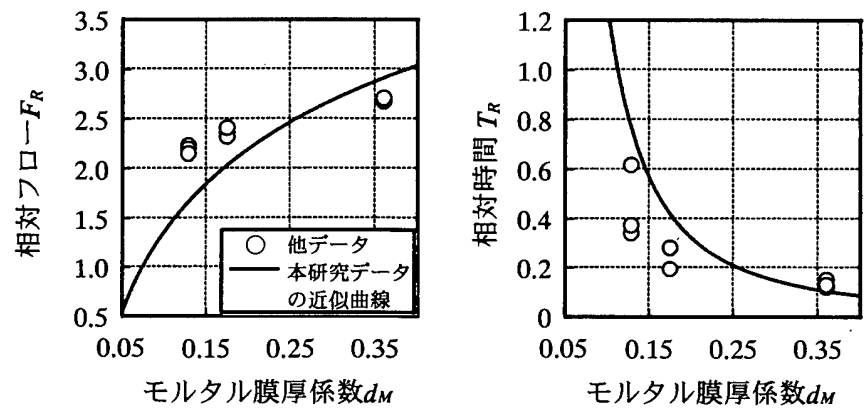

図ー13 他データと本研究データの評俩結果の比較

6) 吉野公、西林新藏、井上正一、黒田保：モルタルのレオロジー定数に及 ほす使用材料の性質の影響、コンクリート工学年次論文報告集、Vol.16、 No.1、pp.461-466、1994

7) 吉野公、西林新蔵、井上正一、黒田保 : コンクリートのレオロジー定数 に及ぼす使用材料の影響、コンクリート工学年次論文報告集、Vol.17、No.1、 p. $581-586 、 1995$

8) 松下博通、田中邦博、近田孝夫 : 碀砂コンクリートの細骨材率に関する 一考察、セメント技術年報、42、pp.88-91、1988

9) 松下博通、近田孝夫: 余剩ペースト理論の配合設計への適用に関する研 究、セメント・コンクリート論文集、No.43、pp.84-89、1989

10) 松下博通、近田孝夫、前田悦孝: コンクリートの配合設計への余剩ペース 卜理論の適用に関する基礎的研究、土木学会論文集、No.578/N-37、pp.57-70、 1997.11

11）寺田謙一、谷川恭雄、森博喟、黒川善幸、三島直生 : 形状保数による粗骨 材の比表面積の簡易測定法、日本建築学会大会学術講演梗概集(九州)、A-1、 pp.549-550、1998.9

12) 三島直生、谷川恭雄、森博罒、寺田謙一：フレッシュコンクリートのせん 断変形性賀における圧力低存性および寸法効果に関する実験的研究（その 1 : 実験概要)、日本建築学会大会学術講演梗概集(近畿)、A-1、pp.447-448、 1996.9

13）寺田謙一、谷川恭雄、森博呞、黒川善幸、三島直生 : フレッシュコンクリ 一トのレオロジー性質に及ぼすせん断層厚さおよび粗骨材要因の影響に 関する研究、日本建築学会構造系論文集、No.513、pp.15-22、1998.11

14）須藤栄治、五味信治、松尾暁、桝田佳寛: 高流動コンクリートの流動性予 測に関する実験的研究、コンクリート工学年次論文報告集、Vol.21、No.2、 pp.511-516、1999 